\title{
Yields and Soil Quality under Transitional Organic High Tunnel Tomatoes
}

\author{
Jennifer Reeve ${ }^{1}$ and Dan Drost \\ Plants, Soils and Climate Department, Utah State University, 4820 Old Main \\ Hill, Logan, UT 84322-4820
}

Additional index words. Solanum lycopersicum, protected cultivation, hoophouse, organic production, organic soil fertility, soil quality

\begin{abstract}
Interest in unheated plastic film-covered high tunnels to extend the growing season of high-value fruits and vegetables is growing rapidly, but sustainable soil management in intensively managed high tunnels is challenging. Yields, fruit quality, and soil quality in transition organic and conventional tomato were measured over the course of three growing seasons. Nitrogen $(N)$ was applied at the rate of 112, 168, and $224 \mathrm{~kg}$ total $\mathrm{N} / \mathrm{ha}$ in the form of chicken manure compost to the organic treatments and a polymercoated slow-release urea fertilizer in the conventional treatments. Marketable yield of organically grown tomatoes was lower in Year 1 but equaled conventional tomatoes in Years 2 and 3. Soil quality as measured by total carbon (C) and $\mathbf{N}$ and microbial activity was significantly greater in organic tomato production at the end of the study. Significant phosphorus (P) and potassium (K) applied with the composted manure resulted in high soil $P$ and $K$ levels in organically managed high tunnels after just 3 years of application. Although compost is the most economical organic fertilizer and results in significant benefits in soil quality during the transition phase to organic production, a maintenance fertility plan is needed once available soil $P$ reaches adequate to high levels. Combinations of compost and high $N$, low $P$ organic fertilizers are needed for optimum maintenance fertility strategy for organic tunnel house production.
\end{abstract}

Use of unheated plastic film-covered high tunnels to extend the growing season of highvalue fruits and vegetables is increasing rapidly in the United States (Lamont, 2009). Driven by strong consumer demand for local and organic produce, there is growing interest in high tunnels for both organic and conventional production (Conner et al., 2009). Expanding the window in which fruits and vegetables can be produced locally allows growers to better meet this emerging market. High tunnels can be constructed cheaply and easily from readily available materials, and cool-season vegetables can even be produced year round in some regions without the need for supplemental heating. High tunnels are routinely used to enhance early-season growth and productivity (Lamont, 2005). They are used to increase the average daily temperature and protect plants from wind,

Received for publication 26 July 2011. Accepted for publication 14 Nov. 2011.

Funding was provided by grants from the Western Sustainable Agriculture Research and Education (project \#SW07-035) program, the Utah Department of Agriculture and Food-Specialty Crop Block Grant program, and from the Utah Agricultural Experiment Station-Utah State University (journal paper number 8336).

We gratefully acknowledge the technical assistance of James Frisby and Alicia Campbell.

Use of trade names does not imply an endorsement of the products named or criticism of similar ones not named.

${ }^{1}$ To whom reprint requests should be addressed; e-mail jennifer.reeve@usu.edu. rain, snow, hail, insects, and diseases. In the high mountain valleys of the Intermountain West, warm-season vegetables like tomatoes are generally planted outdoors in mid- to late May with harvest beginning in late July or early August. High tunnels are used to advance the planting dates by 4-6 weeks and the harvest dates by a month or more.

Maintaining soil quality and fertility in a sustainable manner is challenging in intensively cropped systems such as high tunnels (Montri and Biernbaum, 2009). Intensively tilled soils can develop hard pans, cloddy structure, surface crusting, and loss of organic matter. These problems negatively affect plant growth and are indicators of reduced soil quality (Celik et al., 2004; Shepherd et al., 2002). Conventional farming is often criticized for low nutrient use efficiency of highly soluble fertilizers, which are susceptible to loss to the environment (Byrnes, 1990). Fertility management is also a challenge in organic production as a result of the high variability in nutrient content and availability of organic fertilizers (Gaskell and Smith, 2007). Organic tunnel house producers often rely on plant- and/or manure-based compost to provide their nutrient needs because it is relatively cheap and often readily available locally. In a survey of high tunnel growers in the central Great Plains, 35\% of respondents used organic amendments as their sole nutrient source (Knewtson et al., 2010a). Organic additions were made on an annual basis by $62 \%$ of the growers and $13 \%$ said they applied them more than once per year. In addition to providing nutrients, plant- and manure-based composts also build soil organic matter and soil quality, which is particularly important in highly disturbed, intensively managed systems (Rosen and Allan, 2007). However, if compost is relied on to supply all crop $\mathrm{N}$ needs, or applied in large amounts as a soil conditioner, yields can suffer, at least in the short term, as a result of variability in $\mathrm{N}$ mineralization rates (Hartz et al., 2000). In addition, when composts are applied continuously, growers risk excessive $\mathrm{P}, \mathrm{K}$, and trace element buildup, posing risks for nutrient uptake imbalances and loss to the environment (Gaskell and Smith, 2007; Montri and Biernbaum, 2009). Manure-based composts can be particularly high in salts and trace elements; however, heavy use of plant-based composts can also present these risks because $\mathrm{N}$ is reactive and prone to loss during the composting process while salts accumulate. Opportunities for growing $\mathrm{N}$-fixing cover crops or living mulches can be limited in intensively managed systems such as high tunnels when continued production is often needed for adequate return on investment and to supply year-round markets (Montri and Biernbaum, 2009). This presents a significant conundrum, particularly for nutrient management in organic production systems.

Matching peak crop demands with available nutrients is particularly critical in vegetable crops as a result of their rapid growth and relatively short growing cycles (Gaskell and Smith, 2007). The uncertainty over the availability of nutrients from composts and potential for yield reductions produces doubts in the minds of many growers on how best to transition to organic high tunnel production. At issue is how to manage the tradeoffs between supplying adequate plant-available nutrients and building soil organic matter and soil quality without causing nutrient imbalances or excessive $P$ buildup. Although growers are concerned about soil quality and want to carefully manage the soil environment in high tunnels, $45 \%$ of growers surveyed responded that they did not conduct soil tests (Knewtson et al., 2010a). Interestingly, soil quality (measured as clods, surface crusting, mineral deposition, hardpans, and particulate organic matter) in high tunnels does not appear to be adversely impacted by most growers practices (Knewtson et al., 2010b).

Compost has a strong carryover effect and yields could be expected to improve once a steady state is achieved between inputs of marginally available organic $\mathrm{N}$ and carryover from applications made in previous years (DeLuca and DeLuca, 1997; Endelman et al., 2010). Whether this actually occurs is debatable as a result of a potential mismatch between peak crop requirements and compost mineralization rates (Gaskell and Smith, 2007). Various organically allowable soluble fertilizers produced from plant, fish, and slaughterhouse byproducts are available, but these are very expensive and are likely as susceptible to leaching as conventional fertilizers. Many of these products provide a good source of readily available $\mathrm{N}$ but have the same narrowly defined $\mathrm{N}: \mathrm{P}$ ratio that many 
composts do. Overfertilization in high tunnels can reduce plant health, increase disease or insect problems, and lead to the buildup of excessive soluble salts and nutrient levels (Magdoff and van Es, 2000; Montri and Biernbaum, 2009).

Tomatoes are one of the more commonly grown fresh vegetables and widely grown in high tunnels (Carey et al., 2009; USDA-ERS, 2010). In studies comparing organic with inorganic fertilizers for the production of highly managed greenhouse tomatoes, most showed that productivity levels were similar (Kumar et al., 2007; Rippy et al., 2004) or lower than the yields from plants receiving inorganic fertilizer sources (Heeb et al., 2005, 2006). Heeb et al. (2005) noted that even with a $20 \%$ increase in total $\mathrm{N}$ inputs, lower yields with organic fertilizer were probably the result of insufficient nutrient supply because the availability is low and difficult to predict.

This study was initiated to compare the yields of transition organic and conventional tomatoes grown at varying $\mathrm{N}$ rates in unheated high tunnels and to compare crop productivity, soil quality, and soil fertility. In particular, we were interested in the economic/soil quality tradeoffs of using compost vs. commercial fertilizers in the transition to organic high tunnel production.

\section{Materials and Methods}

Experiments were conducted in four identical high tunnels on the Greenville Research Farm in North Logan, UT (lat. $41.77^{\circ} \mathrm{N}$, long. $111.81^{\circ} \mathrm{W}, 1382 \mathrm{~m}$ elevation, 135 frost-free days) from 2006 to 2008 . The high tunnels $(12.8 \times 4.3 \times 2.6 \mathrm{~m}$ high $)$ were constructed in 2005 of polyvinyl chloride tunnels covered with a single layer of $144-\mu \mathrm{m}$ greenhouse plastic and oriented with their end walls facing eastwest (Black et al., 2008a). The soil type was a Millville silt loam (Coarse-silty, carbonatic, mesic Typic Haploxerolls) that had been fallow for 1 year before tunnel construction. Soil test results before compost or fertilizer applications indicated a $\mathrm{pH}$ of 7.5 with $14 \mathrm{mg} \cdot \mathrm{kg}^{-1}$ of $\mathrm{P}, 138 \mathrm{mg} \cdot \mathrm{kg}^{-1}$ of $\mathrm{K}$, organic matter of $1.1 \%$, and salinity of $1.30 \mathrm{dS} \cdot \mathrm{m}^{-1}$.

Site preparation. Each high tunnel was prepared before transplanting by tilling the soil, incorporating the soil amendments, and laying drip irrigation tape and black plastic mulch over the planting rows. Two high tunnels were managed organically and the other two by conventional approaches; thus, tunnels served as replicates. Although two replicates are the very minimum for valid statistical analysis, we were constrained by costs from including more. Each tunnel contained three planting rows $(12 \mathrm{~m}$ long $\times 0.91 \mathrm{~m}$ wide with $0.61 \mathrm{~m}$ between the rows) and the rows were divided into three 4-m sections (nested replications), which comprised the three fertilizer treatments. In the organically managed tunnels, composted poultry manure (Fassio Farms, Erda, UT) was applied to provide 112, 168 , or $224 \mathrm{~kg}$ total N/ha. Compost was tested each year by Midwest Laboratories (Omaha, $\mathrm{NE}$ ) for $\mathrm{N}-\mathrm{P}-\mathrm{K}$ and trace minerals. Composted poultry manure had a mean total $\mathrm{N}-\mathrm{P}-\mathrm{K}$ content of $16.7 \mathrm{~g} \cdot \mathrm{kg}^{-1}( \pm 3.46 \mathrm{SE}), 22.7 \mathrm{~g} \cdot \mathrm{kg}^{-1}$ $( \pm 1.32)$, and $18.1 \mathrm{~g} \cdot \mathrm{kg}^{-1}( \pm 1.44)$ respectively, and a C:N ratio of 8.2:1 ( \pm 0.29$)$. Compost additions were based on the yearly $\mathrm{N}$ analysis in the organic system and no additional $\mathrm{N}$ was applied during the production season. The $\mathrm{N}$ fertilizer for the conventionally managed tunnels was supplied from a 50:50 blend of POLYON® 42:43 ControlledRelease Fertilizer (Agrium Advanced Technologies, Loveland, CO) applied to supply 112,168 , and $224 \mathrm{~kg} \mathrm{~N} / \mathrm{ha}$. These polymercoated, POLYON® 42:43 controlled-release fertilizers have an estimated release of 90 and $120 \mathrm{~d}$, respectively, at $20^{\circ} \mathrm{C}$. No additional N fertilizer was applied during the growing season. In the conventional tunnels, we also applied $20 \mathrm{~kg} \cdot \mathrm{ha}^{-1} \mathrm{P}$ as triple superphosphate and $75 \mathrm{~kg} \cdot \mathrm{ha}^{-1} \mathrm{~K}$ as potassium chloride as recommended by the soil test. At the start of each subsequent growing season, the same treatments and rates were applied to the same plots in each tunnel. One line of drip tape (TSystems International, San Diego, CA) with $10-\mathrm{cm}$ emitter spacing (flow rate $220 \mathrm{~L} / \mathrm{h}$ ) was installed for irrigation and Watermark ${ }^{\circledR}$ sensors (Irrometer Company, Riverside, CA) were used to monitor soil moisture and schedule irrigations. Watermark ${ }^{\circledR}$ sensors were placed at 15 - and $30-\mathrm{cm}$ soil depth at two locations in each tunnel and soil water content was maintained between 20 and $45 \mathrm{kPa}$. On average, tomato plants were irrigated one time per week early in the year and more frequently as the season progressed (three to four times per week). Other than fertilizer, all other management practices were the same between treatments.

Transplant production and planting. 'Sunbrite' (Seminis Seeds, St. Louis, MO) tomatoes were grown for 8 weeks in a heated greenhouse before being transplanted to the high tunnels. Fifty-cell flats were seeded on 12 Feb. 2006 and 1 Feb. 2007 and 2008 for transplanting later in the spring. Greenhouse temperatures were maintained at $21^{\circ} \mathrm{C}$ during the day and $18^{\circ} \mathrm{C}$ at night, and the daylength was extended to $16 \mathrm{~h}$ using sodium halide lights. Plants were brushed lightly by hand each day to strengthen the stems. All transplants were grown using the TIPI produce mix and fertilized twice weekly with organic fish emulsion followed organic production approaches to ensure uniformity and similarity of planting material (Kuepper and Everett, 2010). Tomatoes (five to six leaf stage) were transplanted on 5 Apr. 2006, 29 Mar. 2007, and 28 Mar. 2008.

For the purposes of this study, tomatoes were grown in the same tunnels each year and rotation with other crops was not considered. The in-row spacing was $45 \mathrm{~cm}$ apart with a total of eight plants per plot. To protect the plants from frost, plants were covered with Reemay $^{\mathrm{TM}}\left(17 \mathrm{~g} \cdot \mathrm{m}^{-2}\right.$; Old Hickory, TN) until early May when night temperatures were no longer likely to drop below freezing. The tunnels were cross-ventilated by opening the doors and lifting the sides of the tunnels when temperatures inside exceeded $30^{\circ} \mathrm{C}$. When night temperatures stayed above $12^{\circ} \mathrm{C}$
(mid-June), the plastic covering the high tunnel was removed and $40 \%$ shadecloth applied. Air temperature at $1 \mathrm{~m}$ high inside the high tunnels was recorded with a CR1000 data logger linked to an AM16/32 multiplexer (Campbell Scientific, Logan, UT) programmed to record high, low, and average hourly temperatures based on readings every $30 \mathrm{~s}$. Temperature data were used to calculate growing degree hours based on the modified ASYMCUR heat unit model (Black et al., 2008b).

Plant growth and yield. Tomato plants were pruned once $\approx 5-6$ weeks after planting and then were grown using a stake and weave system (Jett et al., 2004). Pruning consisted of removing all the suckers below the first dominate secondary shoot on each plant, measuring the total fresh weight, and using this to assess treatment differences. Plants were tied three times with the first string located $\approx 30 \mathrm{~cm}$ high and subsequent strings added in $15-\mathrm{cm}$ intervals. No disease or insect problems were experienced in any of the years in either the organic or conventional production systems.

Tomato harvest began on 1 July 2006, 28 June 2007, and 14 July 2008. Harvest occurred twice per week (Tuesday and Friday) for 4-6 weeks. Tomatoes were harvested at the light red to red stage according to the U.S. standard for color classification (USDA-AMS, 1991). Tomatoes were separated into No. 1 and No. 2 grades according to the U.S. standards, and any other fruits were classified as culls. Fruits were further graded by size and separated into four categories: large (greater than $7.6 \mathrm{~cm})$, medium $(6.4-7.6 \mathrm{~cm})$, small $(5.1-6.4 \mathrm{~cm})$, and cull (less than $5.1 \mathrm{~cm}$; cracked or other defects). Fruits in each class were then counted and weighed. At the end of the study, two to four whole plants were harvested, separated into vines and fruits, and fresh weight measured to assess biomass differences between the production systems and fertilizer rates.

Soil assessments. Soils were sampled to a depth of 0-15 cm and 15-30 cm in Apr. 2008. All samples were a composite of five subsamples taken from each plot. Soil samples were passed through a $2-\mathrm{mm}$ sieve, stored at $4{ }^{\circ} \mathrm{C}$, and then analyzed for the following properties according to recommended soil testing methods by Gavlak et al. (2003): nitratenitrogen $\left(\mathrm{NO}_{3}^{-}-\mathrm{N}\right)$ was measured with the chromotropic acid method (Method S3.30); ammonium-N $\left(\mathrm{NH}_{4}{ }^{+}-\mathrm{N}\right)$ was measured with the salicylate method (Method S3.50); Olsen extractable P and K (Method S4.10); and DTPA-extractable zinc, manganese, copper, and iron (Method S6.10). Soil $\mathrm{pH}$ and electrical conductivity were measured in a $1: 1 \mathrm{w} / \mathrm{v}$ water-saturated paste; water-extractable calcium, magnesium, sodium, boron, and sulfur were measured using the saturation paste method (Method S1.60). Total N was measured by combustion (LECO TruSpec CN; LECO Inc., St. Joseph, MI) and total and inorganic $\mathrm{C}$ was measured using a multicarbon analyzer (LECO RC-412; LECO Inc.) and organic $\mathrm{C}$ determined by a difference as described in the operating manual. Readily 
mineralizable carbon (RMC), basal microbial respiration (BR), and active microbial biomass by substrate-induced respiration (SIR) were measured according to Anderson and Domsch (1978). Ten grams of wet weight soil was brought to $22 \%$ moisture content $(-0.033$ $\mathrm{MPa}$ ) and incubated at $24{ }^{\circ} \mathrm{C}$ for $14 \mathrm{~d}$. Total $\mathrm{CO}_{2}$ released after $14 \mathrm{~d}$ was considered RMC. Vials were recapped for $2 \mathrm{~h}$ and the hourly rate measured for BR. For SIR, $0.5 \mathrm{~mL}$ of $60 \mathrm{~g} \cdot \mathrm{L}^{-1}$ aqueous solution of glucose was added to the same soil samples and rested for $1 \mathrm{~h}$ before being recapped for $2 \mathrm{~h}$. Carbon dioxide was measured in the headspace using an infrared gas analyzer (Model 6251; LICOR Biosciences, Lincoln, NE). Dehydrogenase enzyme activity was measured using $2.5 \mathrm{~g}$ dry weight soil and acid and alkaline phosphatase enzyme activity using $1 \mathrm{~g}$ dry weight soil as described by Tabatabai (1994). Both enzyme reactions were measured using a microplate reader (Spectramax M2; Molecular Devices, Sunnyvale, CA).

Comparisons of soil properties and tomato yield under organic and conventional management were analyzed as a two-way completely randomized design mixed model with fertilizer rate nested within the management system. Year and soil depth were analyzed separately to simplify the model because year-bytreatment and depth interactions were not considered of interest to the study. All data were analyzed using Proc GLIMMIX in the SAS system for Windows Version 9.1 to calculate analysis of variance and least-square means (LSmeans; SAS Institute, Cary, NC). Data were checked for model assumptions and when normality or equality of variance was not met, were square root or log transformed. When data were transformed, LSmeans reported are in original units.

\section{Results}

Plant growth and yield. During the 3 years of this project, the planting date varied by 1 week, whereas the date of first harvest varied by more than 2 weeks (Table 1 ). Climatic conditions during the first $60 \mathrm{~d}$ varied greatly between the years and were a contributing factor in altering crop maturation. In 2006 and 2007, more than 7200 growing degree-hours (base $10{ }^{\circ} \mathrm{C}$ ) accumulated, which was $1000 \mathrm{~h}$ more than accumulated in 2008. Regardless of the year, plant losses resulting from chilling or freezing conditions in the first month after

Table 1. Organic and conventional tomato production details (2006-2008).

\begin{tabular}{lcrc}
\hline & \multicolumn{3}{c}{ Production details } \\
\cline { 2 - 4 } & 2006 & 2007 & 2008 \\
\hline Planting date & 5 Apr. & 29 Mar. & 28 Mar. \\
Pruning date & 5 May & 7 May & 15 May \\
First harvest date & 1 July & 28 June & 14 July \\
Final harvest date & 2 Aug. & 10 Aug. & 28 Aug. \\
& & & \\
GDH & & & \\
First 30 d & 3031 & 2949 & 2461 \\
First 60 d & 7896 & 7268 & 6299 \\
\hline
\end{tabular}

$\overline{\mathrm{GDH}}=$ average growing degree-hours $\left(10{ }^{\circ} \mathrm{C}\right)$ accumulated in high tunnels. planting averaged less than 4\% (data not shown).

Sucker pruning was used as an indirect estimate of early-season plant growth (Table 2). In 2006 and 2007, total pruning fresh weight was significantly $(P \leq 0.01)$ less when tomatoes were grown with compost than when fertilized by conventional means. Although the interaction between fertilizer source and rate was not significant in 2006 or 2007, as fertilizer rate increased from 112 to $224 \mathrm{~kg} \mathrm{~N} /$ ha, pruning biomass increased linearly. However, in 2008, there was no difference between fertilizer sources or fertilizer $\mathrm{N}$ rates for pruning biomass. Pruning weights measured in 2008 were significantly $(P \leq 0.05)$ lower than those recorded in the prior 2 years although the plants grew for an extra week before data collection. Fewer growing degree-hours accumulated in 2008 (Table 1). The cooler weather conditions were a contributing factor to less plant growth during the spring of 2008 relative to 2006 and 2007.

Marketable yield of ripe tomatoes was significantly influenced by fertilizer source in 2006 but not during 2007 or 2008 (Table 3). In 2006, tomatoes fertilized with conventional fertilizer had twice the marketable yield as those fertilized with composted poultry manure. These differences were the result of an increase in the weight of large, medium, and small first- and second-grade fruits. Although marketable yields were not different in 2007 , the weight of large-diameter fruits harvested from tomatoes in the conventional management system was greater $(P \leq 0.05)$ than those managed organically. In contrast, there were significantly $(P \leq 0.05)$ more small No. 1 and No. 2 grade fruits from organic plants compared with those managed conventionally. In general, increasing the fertilizer $\mathrm{N}$ rate did not significantly influence total marketable fruit

Table 2. Effect of fertilizer source and nitrogen rate on pruning dry weight and final tomato fresh weight (2006-2008).

\begin{tabular}{|c|c|c|c|c|c|c|}
\hline \multirow[b]{2}{*}{ Source or rate } & \multicolumn{3}{|c|}{ Pruning dry wt $(\mathrm{g}) /$ plant } & \multicolumn{3}{|c|}{ Final fresh wt $(\mathrm{kg}) /$ plant } \\
\hline & 2006 & 2007 & 2008 & 2006 & 2007 & 2008 \\
\hline Organic & 6.39 & 11.21 & 6.43 & 1.32 & 1.39 & 2.21 \\
\hline \multirow[t]{2}{*}{ Conventional } & 15.08 & 14.15 & 6.91 & 1.94 & 1.63 & 2.26 \\
\hline & $* *$ & $* *$ & NS & $*$ & $*$ & NS \\
\hline $112 \mathrm{~kg} \mathrm{~N} / \mathrm{ha}$ & 7.86 & 11.36 & 6.49 & 1.57 & 1.25 & 2.12 \\
\hline $168 \mathrm{~kg} \mathrm{~N} / \mathrm{ha}$ & 10.54 & 12.60 & 6.83 & 1.64 & 1.55 & 2.38 \\
\hline \multirow[t]{2}{*}{$224 \mathrm{~kg} \mathrm{~N} / \mathrm{ha}$} & 13.79 & 14.08 & 6.70 & 1.68 & 1.72 & 2.21 \\
\hline & $\mathrm{L}^{*}$ & $\mathrm{~L}^{* *}$ & NS & $\mathrm{L}^{*}$ & $\mathrm{~L}^{* *}$ & NS \\
\hline
\end{tabular}

Interaction between fertilizer source and $\mathrm{N}$ rate was not significant in any year.

Ns, *, **Nonsignificant or significant response at $P \leq 0.05$ or 0.01 , respectively.

$\mathrm{L}=$ linear.

Table 3. Influence of fertilizer source and nitrogen rate on the marketable yield $(\mathrm{kg} / \mathrm{plant})$ of first- and second-quality tomato fruits (2006-2008).

\begin{tabular}{|c|c|c|c|c|c|c|c|c|c|}
\hline \multirow[b]{3}{*}{ Source or rate } & \multicolumn{8}{|c|}{ Fruit wt $(\mathrm{kg})$ per plant } & \multirow{3}{*}{$\begin{array}{c}\text { Total } \\
\text { mkt }\end{array}$} \\
\hline & \multicolumn{4}{|c|}{ No. 1 Quality } & \multicolumn{4}{|c|}{ No. 2 Quality } & \\
\hline & Large & Medium & Small & Very small & Large & Medium & Small & Very small & \\
\hline & & & & & 2006 & & & & \\
\hline Organic & 0.15 & 0.87 & 0.19 & 一 & - & 0.61 & - & - & 1.83 \\
\hline Conventional & $\begin{array}{c}0.40 \\
* *\end{array}$ & $\begin{array}{c}1.96 \\
* *\end{array}$ & $\begin{array}{c}0.36 \\
* *\end{array}$ & - & - & $\begin{array}{c}0.88 \\
* *\end{array}$ & - & - & $\begin{array}{c}3.60 \\
* *\end{array}$ \\
\hline $112 \mathrm{~kg} \mathrm{~N} / \mathrm{ha}$ & 0.26 & 1.41 & 0.29 & - & - & 0.72 & - & - & 2.67 \\
\hline $168 \mathrm{~kg} \mathrm{~N} / \mathrm{ha}$ & 0.29 & 1.39 & 0.26 & - & — & 0.67 & - & - & 2.60 \\
\hline \multirow[t]{3}{*}{$224 \mathrm{~kg} \mathrm{~N} / \mathrm{ha}$} & 0.29 & 1.45 & 0.29 & - & - & 0.84 & - & - & 2.87 \\
\hline & NS & NS & NS & NS & NS & NS & NS & NS & NS \\
\hline & & & & & 2007 & & & & \\
\hline Organic & 0.64 & 0.77 & 0.35 & 0.10 & 0.51 & 0.51 & 0.28 & 0.09 & 3.24 \\
\hline \multirow[t]{2}{*}{ Conventional } & 0.85 & 0.70 & 0.25 & 0.08 & 0.60 & 0.60 & 0.21 & 0.07 & 3.34 \\
\hline & * & NS & * & NS & NS & NS & * & NS & NS \\
\hline $112 \mathrm{~kg} \mathrm{~N} / \mathrm{ha}$ & 0.42 & 0.46 & 0.21 & 0.06 & 0.30 & 0.37 & 0.18 & 0.05 & 2.05 \\
\hline $168 \mathrm{~kg} \mathrm{~N} / \mathrm{ha}$ & 0.49 & 0.47 & 0.20 & 0.06 & 0.39 & 0.36 & 0.17 & 0.07 & 2.20 \\
\hline \multirow[t]{3}{*}{$224 \mathrm{~kg} \mathrm{~N} / \mathrm{ha}$} & 0.57 & 0.53 & 0.19 & 0.06 & 0.43 & 0.38 & 0.15 & 0.04 & 2.33 \\
\hline & NS & NS & NS & NS & NS & NS & NS & NS & NS \\
\hline & & & & & 2008 & & & & \\
\hline Organic & 1.06 & 0.61 & 0.29 & 0.04 & 0.41 & 0.167 & 0.18 & 0.40 & 2.81 \\
\hline \multirow[t]{2}{*}{ Conventional } & 1.09 & 0.56 & 0.29 & 0.09 & 0.54 & 0.21 & 0.19 & 0.49 & 3.06 \\
\hline & NS & NS & NS & NS & NS & NS & NS & NS & NS \\
\hline $112 \mathrm{~kg} \mathrm{~N} / \mathrm{ha}$ & 1.03 & 0.63 & 0.31 & 0.08 & 0.58 & 0.18 & 0.18 & 0.39 & 3.05 \\
\hline $168 \mathrm{~kg} \mathrm{~N} / \mathrm{ha}$ & 1.05 & 0.59 & 0.33 & 0.06 & 0.47 & 0.21 & 0.20 & 0.50 & 2.98 \\
\hline \multirow[t]{2}{*}{$224 \mathrm{~kg} \mathrm{~N} / \mathrm{ha}$} & 1.16 & 0.53 & 0.23 & 0.05 & 0.39 & 0.18 & 0.17 & 0.44 & 2.77 \\
\hline & NS & NS & NS & NS & NS & NS & NS & NS & NS \\
\hline
\end{tabular}

Interaction between fertilizer source and $\mathrm{N}$ rate was not significant $(P=0.05)$ during any year. Ns, *, **Nonsignificant or significant response at $P \leq 0.05$ or 0.01 , respectively. 
weight or influence grade and quality in any year (Table 3). There was no interaction between fertilizer source and $\mathrm{N}$ rate in any year. The total marketable fruit number was significantly $(P \leq 0.01)$ influenced by fertilizer source in 2006 but not during 2007 or 2008 (Table 4). In 2006 , conventionally managed tomatoes had 1.8 times more marketable fruits as those organically grown $(P \leq 0.01)$. There were more than twice as many large, medium, and small No. 1 grade fruits harvested from the conventionally fertilized plants. By 2007, fertilizer source had no effect on total marketable fruit number but did influence the number of first- and second-grade small fruits produced in organic compared with conventional managed high tunnels. In general, fertilizer $\mathrm{N}$ rate did not influence fruit number in any year (Table 4) and there was no interaction between fertilizer source and $\mathrm{N}$ rate.

After the last harvest, plants from the center of each treatment were harvested to determine residual plant weight (vine + unharvested fruit) (Table 2). In 2006 and 2007, final plant fresh weight was significantly $(P \leq 0.05)$ less for tomatoes grown with compost than when conventional $\mathrm{N}$ fertilizer was applied. By 2008 , there was no difference in final plant fresh weight between tomatoes fertilized with compost or conventional fertilizer. Although the interaction between fertilizer source and $\mathrm{N}$ rate was not significant in any year, in 2006 and 2007, as N fertilizer rate increased (regardless of source), final plant fresh weight increased linearly. There was no difference in residual plant biomass between 2006 and 2007 , but in 2008 , remaining plant weight was $30 \%$ to $50 \%$ greater as a result of a large proportion of unharvested green fruits.

Soil assessment. Soil chemical analyses indicated a number of significant differences between organic and conventionally managed soils at both depths (Table 5). Soil $\mathrm{NO}_{3}{ }^{-} \mathrm{N}$ was three- $(P \leq 0.10)$ and fourfold $(P \leq 0.05)$ greater in the conventionally managed soils at 0-15 and $15-30 \mathrm{~cm}$, respectively. Although soil ammonium N concentration was approximately twofold greater in the conventional soils, this difference was not significant. However, soil $\mathrm{P}$ and $\mathrm{K}$ were significantly $(P \leq$ 0.05 ) greater at $0-15 \mathrm{~cm}$ and $15-30 \mathrm{~cm}$ in the organically managed soils. Available soil $\mathrm{P}$ was 3.5 - and 3.3-fold greater at $0-15$ and $15-30 \mathrm{~cm}$, whereas available $\mathrm{K}$ was 5.2 - and 4.2 -fold greater at $0-15$ and $15-30 \mathrm{~cm}$, respectively. Boron was also significantly $(P \leq 0.05)$ greater in the organically managed soils. Soil $\mathrm{pH}$ was greater $(P \leq 0.10)$ in the organically managed soils at $15-$ to $30-\mathrm{cm}$ depth only (Table 5). There were no differences in soil electrical conductivity (EC) or water-soluble sulfur, sodium, magnesium, or calcium $(\mathrm{Ca})$. Of the chemical analyses measured, only soil nitrate and $\mathrm{EC}$ increased, and $\mathrm{pH}$ decreased by fertilizer rate in both treatments (data not shown). Significant interactions for soil $\mathrm{P}$ and $\mathrm{K}$ showed that soil $\mathrm{P}$ and $\mathrm{K}$ increased with rate in the organically managed soils only (Table 6). Soil $\mathrm{NH}_{4}^{+}$and $\mathrm{Ca}$ increased with increasing fertilizer rate in the conventionally managed soils (Table 6).

Table 4. Influence of fertilizer source and nitrogen rate on the number of first- and second-quality tomato fruits per plant (2006-2008).

\begin{tabular}{|c|c|c|c|c|c|c|c|c|c|}
\hline \multirow[b]{3}{*}{ Source or rate } & \multicolumn{8}{|c|}{ Fruit number per plant } & \multirow{3}{*}{$\begin{array}{c}\text { Total } \\
\text { number }\end{array}$} \\
\hline & \multicolumn{4}{|c|}{ No. 1 Quality } & \multicolumn{4}{|c|}{ No. 2 Quality } & \\
\hline & Large & Medium & Small & Very small & Large & Medium & Small & Very small & \\
\hline & & & & & 2006 & & & & \\
\hline Organic & 0.6 & 6.0 & 2.1 & - & - & 4.3 & - & - & 13.0 \\
\hline \multirow[t]{2}{*}{ Conventional } & 1.6 & 12.2 & 4.3 & - & - & 5.4 & - & - & 23.4 \\
\hline & $* *$ & $* *$ & $* *$ & & & $* *$ & & & $* *$ \\
\hline $112 \mathrm{~kg} \mathrm{~N} / \mathrm{ha}$ & 1.0 & 8.9 & 3.3 & - & - & 4.7 & - & - & 17.8 \\
\hline $168 \mathrm{~kg} \mathrm{~N} / \mathrm{ha}$ & 1.2 & 8.6 & 2.7 & - & - & 4.4 & - & - & 16.9 \\
\hline \multirow[t]{3}{*}{$224 \mathrm{~kg} \mathrm{~N} / \mathrm{ha}$} & 1.2 & 9.7 & 3.6 & - & - & 5.4 & - & - & 19.9 \\
\hline & NS & NS & NS & NS & NS & NS & NS & NS & NS \\
\hline & & & & & 2007 & & & & \\
\hline Organic & 3.0 & 4.8 & 3.7 & 2.3 & 2.1 & 3.3 & 3.0 & 1.7 & 24.0 \\
\hline \multirow[t]{2}{*}{ Conventional } & 3.6 & 4.3 & 2.7 & 1.7 & 2.5 & 3.7 & 2.4 & 1.5 & 23.3 \\
\hline & NS & NS & $*$ & NS & NS & NS & $*$ & NS & NS \\
\hline $112 \mathrm{~kg} \mathrm{~N} / \mathrm{ha}$ & 2.9 & 4.3 & 3.4 & 1.9 & 1.9 & 3.6 & 2.8 & 1.6 & 22.4 \\
\hline $168 \mathrm{~kg} \mathrm{~N} / \mathrm{ha}$ & 3.3 & 4.4 & 3.2 & 2.0 & 2.4 & 3.4 & 2.8 & 1.9 & 23.5 \\
\hline \multirow[t]{3}{*}{$224 \mathrm{~kg} \mathrm{~N} / \mathrm{ha}$} & 3.7 & 4.9 & 3.0 & 2.1 & 2.6 & 3.5 & 2.5 & 1.2 & 23.6 \\
\hline & NS & NS & NS & NS & NS & NS & NS & $*$ & NS \\
\hline & & & & & 2008 & & & & \\
\hline Organic & 3.6 & 3.1 & 2.5 & 0.8 & 1.4 & 0.9 & 1.8 & 1.4 & 15.4 \\
\hline \multirow[t]{2}{*}{ Conventional } & 3.4 & 2.4 & 2.5 & 1.3 & 1.6 & 1.0 & 1.8 & 0.9 & 14.8 \\
\hline & NS & NS & NS & NS & NS & NS & NS & NS & NS \\
\hline $112 \mathrm{~kg} \mathrm{~N} / \mathrm{ha}$ & 3.1 & 2.8 & 2.6 & 1.0 & 1.6 & 0.8 & 1.6 & 1.0 & 14.5 \\
\hline $168 \mathrm{~kg} \mathrm{~N} / \mathrm{ha}$ & 3.4 & 2.7 & 2.9 & 1.2 & 1.6 & 1.0 & 2.0 & 1.3 & 15.9 \\
\hline \multirow[t]{2}{*}{$224 \mathrm{~kg} \mathrm{~N} / \mathrm{ha}$} & 4.1 & 2.8 & 2.1 & 0.9 & 1.3 & 1.0 & 1.7 & 1.1 & 14.9 \\
\hline & NS & NS & NS & NS & NS & NS & NS & NS & NS \\
\hline
\end{tabular}

Interaction between fertilizer source and $\mathrm{N}$ rate was not significant $(P=0.05)$ in any year.

Ns, *, **Nonsignificant or significant response at $P \leq 0.05$ or 0.01 , respectively.

Table 5. Means ( $\mathrm{n}=2)$ of soil ( 0 - to 15 - and 15 - to 30 -cm depth) chemical analyses. ${ }^{2}$

\begin{tabular}{|c|c|c|c|c|}
\hline Soil property (g soil) & $\begin{array}{c}\text { Organic } \\
0 \text { - to } 15-\mathrm{cm} \\
\text { depth }\end{array}$ & $\begin{array}{c}\text { Conventional } \\
\begin{array}{c}\text { 0- to } 15-\mathrm{cm} \\
\text { depth }\end{array}\end{array}$ & $\begin{array}{c}\text { Organic } \\
\begin{array}{c}15-\text { to } 30-\mathrm{cm} \\
\text { depth }\end{array}\end{array}$ & $\begin{array}{c}\frac{\text { Conventional }}{15 \text { - to } 30-\mathrm{cm}} \\
\text { depth }\end{array}$ \\
\hline Nitrate $\left(\mathrm{mg} \cdot \mathrm{kg}^{-1}\right)$ & 9.61 & $28.6^{*}$ & 1.70 & $6.67 * *$ \\
\hline Ammonium $\left(\mathrm{mg} \cdot \mathrm{kg}^{-1}\right)$ & 0.90 & 2.16 & 0.67 & 1.48 \\
\hline Phosphorus (Olsen) (mg. $\left.\mathrm{kg}^{-1}\right)$ & $136^{* * *}$ & 39.1 & $72.3 * *$ & 21.9 \\
\hline Potassium (Olsen) $\left(\mathrm{mg}^{\mathrm{kg}} \mathrm{kg}^{-1}\right)$ & $529 * *$ & 101 & $335^{* *}$ & 79.0 \\
\hline $\mathrm{pH}$ & 8.40 & 8.22 & $8.67 *$ & 8.49 \\
\hline Electrical conductivity $\left(\mu \mathrm{S} \cdot \mathrm{cm}^{-1}\right)$ & 336 & 367 & 163 & 184 \\
\hline Sulfur $\left(\mathrm{mg} \cdot \mathrm{kg}^{-1}\right)$ & 18.9 & 17.5 & - & - \\
\hline Boron $\left(\mathrm{mg} \cdot \mathrm{kg}^{-1}\right)$ & $0.15 * *$ & 0.08 & - & - \\
\hline Potassium (water-soluble) $\left(\mathrm{mg} \cdot \mathrm{kg}^{-1}\right)$ & $15.2^{* *}$ & 2.50 & - & - \\
\hline Sodium $\left(\mathrm{mg} \cdot \mathrm{kg}^{-1}\right)$ & 29.7 & 10.3 & - & - \\
\hline Magnesium $\left(\mathrm{mg} \cdot \mathrm{kg}^{-1}\right)$ & 14.3 & 19.1 & - & - \\
\hline Calcium $\left(\mathrm{mg} \cdot \mathrm{kg}^{-1}\right)$ & 39.8 & 82.6 & - & - \\
\hline
\end{tabular}

${ }^{2}$ Soil data collected in 2008 after three seasons of transition to organic management.

Means designated $*, * * * *$ are significant at $P \leq 0.10,0.05$, or 0.01 , respectively.

Table 6. Means $(\mathrm{n}=3)$ of soil $\left(0\right.$ - to 15 -cm depth) chemical analyses. ${ }^{\mathrm{z}}$

\begin{tabular}{|c|c|c|c|c|c|c|}
\hline Soil Property (g soil) & $\begin{array}{l}\text { Organic } \\
\text { high rate }\end{array}$ & $\begin{array}{c}\text { Organic } \\
\text { medium rate }\end{array}$ & $\begin{array}{l}\text { Organic } \\
\text { low rate }\end{array}$ & $\begin{array}{l}\text { Conventional } \\
\text { high rate }\end{array}$ & $\begin{array}{l}\text { Conventional } \\
\text { medium rate }\end{array}$ & $\begin{array}{c}\text { Conventional } \\
\text { row rate }\end{array}$ \\
\hline$\overline{\text { Ammonium }(\mu \mathrm{g})}$ & $0.57 \mathrm{Aa}^{\mathrm{y}}$ & $1.28 \mathrm{Aa}$ & $0.84 \mathrm{Aa}$ & $3.97 \mathrm{Aa}$ & $0.84 \mathrm{Ab}$ & $1.26 \mathrm{Aab}$ \\
\hline $\begin{array}{l}\text { Phosphorus (Olsen) } \\
\quad(\mu \mathrm{g})\end{array}$ & $153 \mathrm{Aa}$ & $136 \mathrm{Aab}$ & $120 \mathrm{Abc}$ & $40.3 \mathrm{Ba}$ & $37.3 \mathrm{Ba}$ & $39.7 \mathrm{Ba}$ \\
\hline Potassium $(\mu \mathrm{g})$ & 636 & 534 & 416 & & & $111 \mathrm{I}$ \\
\hline Calcium, & $37.9 \mathrm{Ba}$ & $46.9 \mathrm{Ba}$ & $34.4 \mathrm{Ba}$ & $105.9 \mathrm{Aa}$ & $83.0 \mathrm{Ab}$ & $58.9 \mathrm{Bc}$ \\
\hline
\end{tabular}

${ }^{2}$ Soil data collected in 2008 after three seasons of transition to organic management.

${ }^{y}$ Upper case letters represent between treatment effects. Lower case letters represent within treatment rate effects $P \leq 0.05$.

Soil biological analyses were also significantly different between organic and conventional management (Table 7). Soil organic C was significantly greater $(P \leq 0.05)$ in the organically managed soils at $0-15 \mathrm{~cm}$ and greater $(P \leq 0.10)$ at 15 - to $30-\mathrm{cm}$ depth. Total soil $\mathrm{N}$ was $152 \%$ greater in organically managed soils, but this difference was not significant $(P=0.114)$. Microbial activity as measured by acid phosphatase was greater $(P \leq 0.01)$ in the organically managed soils in the top $0-15 \mathrm{~cm}$, whereas dehydrogenase and alkaline phosphatase were greater $(P \leq$ $0.10)$ in organically managed soils at $0-15 \mathrm{~cm}$. Readily mineralizable $\mathrm{C}$ was greater $(P \leq$ $0.05)$ in the organically managed soils at 
Table 7. Means $(\mathrm{n}=2)$ of soil $\left(0-\right.$ to $15-\mathrm{cm}$ and 15 - to $30-\mathrm{cm}$ depth) biological analyses. ${ }^{\mathrm{z}}$

\begin{tabular}{|c|c|c|c|c|}
\hline & Organic & Conventional & Organic & Conventional \\
\hline Soil property (g soil) & $\begin{array}{l}0 \text { - to } 15-\mathrm{cm} \\
\text { depth }\end{array}$ & $\begin{array}{l}0 \text { - to } 15-\mathrm{cm} \\
\text { depth }\end{array}$ & $\begin{array}{l}\overline{15-\text { to } 30-\mathrm{cm}} \\
\text { depth }\end{array}$ & $\begin{array}{l}\text { 15- to } 30-\mathrm{cm} \\
\text { depth }\end{array}$ \\
\hline Organic carbon $\left(\mathrm{mg} \cdot \mathrm{kg}^{-1}\right)$ & $14,763 * * *$ & 7,177 & $7,500^{*}$ & 6,735 \\
\hline Total nitrogen $\left(\mathrm{mg} \cdot \mathrm{kg}^{-1}\right)$ & 651 & 258 & 1,299 & 969 \\
\hline Dehydrogenase, $\mu \mathrm{g}$ TPF (g soil) & $5.31 *$ & 3.64 & 2.27 & 1.42 \\
\hline Acid phosphatase, $\mu \mathrm{g}$ p-nitrophenol (g soil) & $111 * * *$ & 62.2 & - & - \\
\hline $\begin{array}{l}\text { Alkaline phosphatase, } \mu \mathrm{g} \text { p-nitrophenol } \\
(\mathrm{g} \text { soil) }\end{array}$ & $317^{*}$ & 244 & - & - \\
\hline $\begin{array}{l}\text { Readily mineralizable carbon, } \mu \mathrm{g} \mathrm{CO}_{2}-\mathrm{C} \\
\text { g soil) }\end{array}$ & $910 * *$ & 421 & 472 & 279 \\
\hline Basal respiration, $\mu \mathrm{g} \mathrm{CO}_{2}-\mathrm{C}$ (g soil) & 128 & 85.2 & 92.1 & 63.0 \\
\hline Microbial biomass, $\mu \mathrm{g} \mathrm{CO} \mathrm{CO}_{2}-\mathrm{C}$ (g soil) & 6,514 & 5,137 & 4,745 & 4,257 \\
\hline
\end{tabular}

${ }^{\mathrm{z} S o i l}$ data collected in 2008 after three seasons of transition to organic management.

Means designated $* * *, * * *$ are significant at $P \leq 0.10,0.05$, or 0.01 , respectively.

$0-15 \mathrm{~cm}$. There were no significant differences in soil basal respiration or microbial biomass $\mathrm{C}$. None of the biological soil parameters differed significantly by fertilizer rate (data not shown).

\section{Discussion}

Improved environmental conditions in high tunnels allow more accumulation of growing degree-days, which results in earlier maturity (Both et al., 2007; Waterer and Bantle, 2000) and dramatically influenced plant growth in our study. Seasonal variations in growing degree-hours were noted, which influenced the amount of early-season growth (pruning biomass), the date of first harvest, average seasonal productivity, and residual plant weight after harvest. Although outdoor tomato production was not part of this study, local commercially grown tomatoes were not available until early to mid-August. Thus, growers using high tunnels have less competition in local markets and regularly receive higher prices for their produce.

Yield (marketable and grade) of tomatoes was initially lower in organically managed high tunnels; however, this difference was insignificant by the second year of organic management. Others have noted that lower application rates of poultry litter were inadequate for maximum production unless the materials were applied repeatedly over several seasons (Alsup et al., 2002; Brown et al., 1994) or composted (Maynard, 1994, 1995). Initial reduction in yield on conversion to organic production is common and is referred to as the "transition effect" (Hartz et al., 2000; Scow et al., 1994). As organic $\mathrm{N}$ increases from repeated compost or manure applications, cumulative $\mathrm{N}$ mineralization also increases as a result of the carryover effect and yields improve (DeLuca and DeLuca, 1997; Endelman et al., 2010; Rosen and Allan, 2007). The transition effect can be especially severe in soils with low organic matter content such as in Utah as a result of the lack of buffering provided by native soil $\mathrm{N}$ mineralization. Because the compost fertilized plots were clearly $\mathrm{N}$ limited in 2006, the lack of a fertilizer source $\times$ $\mathrm{N}$ rate interaction on yield was surprising and is likely explained by the low number of replicates in the study and a disconnect between plant $\mathrm{N}$ demand and compost $\mathrm{N}$ supply.
Early-season growth (pruning biomass) suggested that productivity may be limited in the organically managed tunnels. During the first transition year (2006), pruning biomass was more than $236 \%$ greater in the conventionally fertilized system, whereas marketable yield was $197 \%$ higher. With additional compost additions in 2007, pruning biomass in the organic system was $21 \%$ lower, but marketable yield was not significantly different from the conventionally managed system. The elimination of this yield discrepancy with time is attributed to the buildup of soil fertility resulting from carryover from previous applications and resulting increased mineralization (Endelman et al., 2010; Hartz et al., 2000; Rosen and Allan, 2007). Lower pruning biomass may be attributed to the cool growing conditions early in the year, which limits $\mathrm{N}$ mineralization. As temperatures increase, plant growth and productivity would improve. If organic produce carries some price premium in the marketplace, then lower initial yields may not limit economic returns and farm profitability.

Soil chemical and biological properties were assessed in the final year of the 3-year transition and significant differences between the organically and conventionally managed high tunnels were observed. Many differences were only marginally significant, although this likely reflects lack of statistical power as a result of the low number of tunnel replicates used in the study. Soil organic C was $206 \%$ greater as a result of compost applications. Soil organic $\mathrm{C}$ is a major constituent of soil organic matter (SOM), which significantly improves soil structure, water infiltration, and water-holding capacity (Brady and Weil, 2002a; Shepherd et al., 2002). Soil organic matter also acts as a source of slow-release nutrients, and the high cation exchange capacity of SOM helps buffer fluctuations in plant-available nutrients. The presence of $\mathrm{P}$ and trace elements in organic and chelated forms improve plant availability (Stewart and Tiessen, 1987). Moreover, organic compounds found in manures and composts may form coatings on soil minerals and slow or prevent the precipitation and fixation of $\mathrm{P}$ and trace elements (Brady and Weil, 2002b, 2002c). Precipitation and fixation of $\mathrm{P}$ are of particular concern in high $\mathrm{pH}$ soils found in the western United States.
Soil organic matter also provides nutrients and $\mathrm{C}$ to the soil microbial biomass. In addition to their role in nutrient cycling, a large and active microbial biomass is considered to play a role in suppressing the proliferation of soilborne diseases, hence contributing to soil quality and health (Janvier et al., 2007). Although not significant, soil microbial biomass under organic management was $128 \%$ greater in this study. Overall microbial activity may be more important in nutrient cycling and disease-suppressive properties than the total size of the microbial biomass, however (Janvier et al., 2007). Microbial activity as measured by dehydrogenase activity was $146 \%$ greater under organic management. Dehydrogenase is generally considered a good indicator of overall soil microbial activity because it is a key enzyme in the oxidation of organic matter (Tabatabai, 1994). Readily mineralizable carbon was $217 \%$ greater under the organic management and is a good indicator of the labile $\mathrm{C}$ pool available to soil microbes and their potential activity. In addition, acid phosphatase was $345 \%$ greater under organic management, whereas alkaline phosphatase was $130 \%$ greater. Both of these enzymes are important in the mineralization of organic P. Although both plants and microorganisms produce acid phosphatase, alkaline phosphatase is thought to be microbially derived only (Tabatabai, 1994). Soil enzymes have been proposed as indicators of overall soil quality (Dick, 1994) and are correlated with labile organic matter compounds, nutrient cycling potential as well as physical attributes such as soil structure and porosity (Celik et al., 2004; Giusquiani et al., 1995), which are essential to maintain yield potential in highly managed systems.

Despite the numerous benefits of compost on soil quality and soil health, overuse of compost can result in rapid accumulation of soil $\mathrm{P}$, soluble salts, and trace elements to levels that may be undesirable (Rosen and Allan, 2007). When compost is used as a soil conditioner or to meet crop $\mathrm{N}$ needs, the potential for $\mathrm{P}$ and salt buildup is high. In a survey conducted in the Midwest by Knewtson et al. (2010a), 85\% of growers reported using organic amendments in their high tunnels, whereas 35\% used organic fertilizers exclusively. Animal manure and homemade compost were the most common nutrient sources; however, $49 \%$ of growers reported they never conducted a soil test, indicating many growers may not be aware how rapidly soil $\mathrm{P}$ and other nutrients can accumulate. Watson et al. (2002) also showed rapid $\mathrm{P}$ and $\mathrm{K}$ buildup in organic horticultural systems. In this study, we found soil P and $\mathrm{K}$ accumulating at levels that greatly exceeded crop needs in a period of only 3 years (Cardon et al., 2008).

Although elevated soil $\mathrm{P}$ is not considered harmful to plants, it can pose a threat to the environment as a result of runoff and leaching of the organically bound forms found in compost and manures (Brady and Weil, 2002b; Rosen and Allan, 2007). Other nutrient imbalances can result in luxury consumption or compete with uptake of essential nutrients causing potential problems with fruit quality 
(Peet, 2005). In the present study, during the time soil $\mathrm{P}$ and $\mathrm{K}$ was accumulating, crop yields matched conventional yields after initially lagging. These findings illustrate the challenge of developing sustainable nutrient management plans for organic specialty crops when $\mathrm{N}$-fixing cover crops are not incorporated into the rotation.

Economically viable tunnel house production must meet the additional challenge of covering the opportunity cost of the structure so including $\mathrm{N}$-fixing cover crops and other less profitable crops into the rotation is not very attractive to growers. Our data show that yields in organic transition tomato production can equal conventional production with the use of poultry manure compost after 2 years. It is important to note that increased fertilizer $\mathrm{N}$ rate did not have a significant effect on fruit number or size in either organic or conventional systems, implying that rates can be reduced to improve both economic outcomes and reduce potential for nutrient loss. The lack of a $\mathrm{N}$ rate response is likely attributable in part to a lack of replications; however, nutrient carry over from year to year, and the timing of $\mathrm{N}$ release relative to the needs of the crop may be contributing factors as well. Nutrient release from compost is associated with mineralization rates, which may be too slow early in the year when soil temperatures in high tunnels are still cool. In the conventionally managed tunnels, $\mathrm{N}$ release from the polymer-coated urea POLYON ${ }^{\circledR}$ is optimal at $20{ }^{\circ} \mathrm{C}$ and is highly temperature-dependent. Cool soil temperatures early in the year may have contributed to insufficient $\mathrm{N}$ availability, although this would require additional studies.

The relatively low cost of poultry manure compost allowed for maximum returns during the transition phase with the concurrent benefit of improved soil quality. Once P levels reach desirable levels, compost should be used at a maintenance rate for soil quality and $\mathrm{P}$ needs only and additional $\mathrm{N}$ supplied through a low-cost N-rich fertilizer such as feather meal (Andrews et al., 2007). Further research on $\mathrm{P}$ management, $\mathrm{N}$ sources, and $\mathrm{N}$ rates that build and maintain soil quality and yields for high tunnel production is needed, in particular, improved crop rotations, integration of plantbased composts, and the use of organic fertilizers that meet the production systems $\mathrm{N}$ needs without supplying other additional nutrients. Because high tunnels are covered during winter and spring when leaching and runoff events are most likely to occur, it could be argued that the potential for contamination is low. If high tunnel production is promoted as a sustainable local alternative to conventional production, this cannot be assumed, however. Further research is therefore needed to determine the leaching potential from summer rains or flooding events from winter storms in nutrient-enriched high tunnels. Low-cost engineering solutions to prevent runoff and leaching from high tunnels also warrant investigation. This type of solution could be particularly useful in urban environments and for growers located near drains and water sources.

\section{Literature Cited}

Alsup, C.M., B.A. Kahn, and M.E. Payton. 2002. Using cowpea to manage soil phosphorus accumulation from poultry litter applications in a cool-season vegetable rotation. HortScience 37:496-501.

Anderson, J.P.E. and K.H. Domsch. 1978. A physiological method for the quantitative measurement of microbial biomass in soil. Soil Biol. Biochem. 10:215-221.

Andrews, N., D. Sullivan, J. Julian, and K. Pool. 2007. OSU organic fertilizer \& cover crop calculator. Oregon State University Cooperative Extension. 11 Nov. 2011. <http://smallfarms. oregonstate.edu/calculator $>$.

Black, B., D. Drost, D. Rowley, and R. Heflebower. 2008a. Construction of a low-cost high tunnel. Utah State University Cooperative Extension. 17 Sept. 2011. <https://extension.usu.edu/files/ publications/publication/HG_High_Tunnels_ 2008-01pr.pdf>.

Black, B., J. Frisby, K. Lewers, F. Takeda, and C. Finn. 2008b. Heat unit model for predicting bloom dates in rubus. HortScience 43:20002004.

Both, A.J., E. Reiss, J.F. Sudal, K.E. Holmstrom, C.A. Wyenandt, W.L. Kline, and S.A. Garrison. 2007. Evaluation of a manual energy curtain for tomato production in high tunnels. HortTechnology 17:467-472.

Brady, N.C. and R.R. Weil. 2002a. Soil organic matter, p. 498-541. In: The nature and properties of soils. 13th Ed. Prentice Hall, Upper Saddle River, NJ.

Brady, N.C. and R.R. Weil. 2002b. Soil phosphorus and potassium, p. 592-637. In: The nature and properties of soils. 13th Ed. Prentice Hall, Upper Saddle River, NJ.

Brady, N.C. and R.R. Weil. 2002c. Micronutrients and other trace elements, p. 638-668. In: The nature and properties of soils. 13th Ed. Prentice Hall, Upper Saddle River, NJ.

Brown, J.E., J.M. Dangler, C.H. Gilliam, D.W. Porch, and R.L. Shumack. 1994. Comparison of broiler litter and inorganic nitrogen, phosphorus, and potassium for double-cropped sweet corn and broccoli. J. Plant Nutr. 17:859-867.

Byrnes, B.H. 1990. Environmental effects of N fertiliser use-An overview. Fert. Res. 26:209215

Cardon, G.E., J. Kotuby-Amacher, P. Hole, and R. Koenig. 2008. Understanding your soil test report. Utah State University Cooperative Extension. 17 Sept. 2011. <http://extension. usu.edu/files/publications/publication/AG_Soils_ 2008-01pr.pdf>

Carey, E.E., L. Jett, W.J. Lamont, Jr., T.T. Nennich, M.D. Orzolek, and K.A. Williams. 2009. Horticultural crop production in high tunnels in the United States: A snapshot. HortTechnology 19:37-43.

Celik, I., I. Ortas, and S. Kilic. 2004. Effects of compost, mycorrhiza, manure and fertilizer on some physical properties of a Chromoxerert soil. Soil Tillage Res. 78:59-67.

Conner, D.S., A.D. Montri, D.N. Montri, and M.W Hamm. 2009. Consumer demand for local produce at extended season farmers' markets: Guiding farmer marketing strategies. Renew. Agr. Food Syst. 24:251-259.

DeLuca, T.H. and D.K. DeLuca. 1997. Composting for feedlot manure management and soil quality. J. Prod. Agr. 10:235-241.

Dick, R.P. 1994. Soil enzyme activities as indicators of soil quality. Soil Sci. Soc. Amer. J. 35:107-124.

Endelman, J.B., J.R. Reeve, and D.T. Drost. 2010. A new decay series for organic crop production. Agron. J. 102:457-463.
Gaskell, M. and R. Smith. 2007. Nitrogen sources for organic vegetable crops. HortTechnology 17:431-441.

Gavlak, R., Horneck, D., Miller, R.O., and KotubyAmacher, J., 2003. Soil and plant reference methods for the Western region. Western Region Extension Publication. WREP 125.

Giusquiani, P.L., M. Pagliai, G. Gigliotti, D Businelli, and A. Benetti. 1995. Urban waste compost: Effects on physical, chemical and biochemical soil properties. J. Environ. Qual. 24:175-182.

Hartz, T.K., J.P. Mitchell, and C. Giannini. 2000. Nitrogen and carbon mineralization dynamics of manures and composts. HortScience 35: 209-212.

Heeb, A., B. Lundegardh, T. Ericsson, and G. Savage. 2005. Effects of nitrate-, ammonium-, and organic-nitrogen-based fertilizers on growth and yield of tomatoes. J. Plant Nutr. Soil Sci. 168:123-129.

Heeb, A., B. Lundegardh, G. Savage, and T. Ericsson. 2006. Impact of organic and inorganic fertilizers on yield, taste, and nutritional quality of tomatoes. J. Plant Nutr. Soil Sci. 169:535-541.

Janvier, C., F. Villeneuve, C. Alabouvette, V. EdelHermann, T. Mateille, and C. Steinberg. 2007. Soil health through soil disease suppression: Which strategy from descriptors to indicators? Soil Biol. Biochem. 39:1-23.

Jett, L., D. Coltrain, J. Chism, J. Quinn, and A. Read. 2004. High tunnel tomato production. University of Missouri Cooperative Extension. 30 Aug. 2011. <http://extension.missouri.edu/ explorepdf/manuals/m00170.pdf $>$.

Knewtson, S.J.B., E.E. Carey, and M.B. Kirkham. 2010a. Management practices of growers using high tunnels in the central Great Plains of the United States. HortTechnology 20:639645 .

Knewtson, S.J.B., R. Janke, M.B. Kirkham, K.A Williams, and E.E. Carey. 2010b. Trends in soil quality under high tunnels. HortScience 45: $1534-1538$

Kuepper, G. and K. Everett. 2010. Potting mixes for certified organic production. NCAT Sustainable Agriculture Project. 17 Sept. 2011. $<$ https://attra.ncat.org/attra-pub/viewhtml.php? id $=47>$.

Kumar, R., D. Klein, A. Krumbein, and U. Kopke. 2007. Product quality of greenhouse tomatoes: Effects of cultivars, organic N-fertilization and harvest time. Europ. J. Hort. Sci. 72:4651.

Lamont, W.J., Jr. 2005. Plastics: Modifying the microclimate for the production of vegetable crops. HortTechnology 15:477-481.

Lamont, W.J., Jr. 2009. Overview of the use of high tunnels worldwide. HortTechnology 19: 25-29.

Magdoff, F. and H. van Es. 2000. Building soils for better crops: Sustainable agriculture network handbook series book 4. Sustainable Agriculture Publications, Burlington, VT.

Maynard, A.A. 1994. Sustained vegetable production for three years using composted animal manures. Compost Sci. Util. 2:88-96.

Maynard, A.A. 1995. Cumulative effect of annual additions of MSW compost on the yield of field-grown tomatoes. Compost Sci. Util. 3:4754.

Montri, A. and J.A. Biernbaum. 2009. Management of the soil environment in high tunnels. HortTechnology 19:34-36.

Peet, M.M. 2005. Irrigation and fertilization, p. 171-198. In: Heuvelink, E. (ed.). Tomatoes. CABI Publishing, Cambridge, MA. 
Rippy, J.F.M., M.M. Peet, F.J. Louws, P.V. Nelson, D.B. Orr, and K.A. Sorensen. 2004. Plant development and harvest yields of greenhouse tomatoes in six organic growing systems. HortScience 39:223-229.

Rosen, C.J. and D.L. Allan. 2007. Exploring the benefits of organic nutrient sources for crop production and quality. HortTechnology 17: 422-430.

Scow, K.M., O. Sinasco, N. Gunapala, S. Lau, R. Venette, H. Ferrris, R. Miller, and C. Shennan. 1994. Transition from conventional to lowinput agriculture changes soil fertility and biology. Calif. Agr. 48:20-26.
Shepherd, M.A., R. Harrison, and J. Webb. 2002. Managing soil organic matter-Implications for soil structure on organic farms. Soil Use Mgt. 18:284-292.

Stewart, J.W.B. and H. Tiessen. 1987. Dynamics of soil organic phosphorus. Biogeochemistry 4:41-60.

Tabatabai, M.A. 1994. Soil enzymes, p. 775-833. In: Weaver, R.W., et al. (eds.). Methods of soil analysis. Part 2, Microbiological and biochemical properties. Soil. Sci. Soc. of Amer., Madison, WI.

USDA-AMS. 1991. United States standards for grades of fresh tomatoes. 17 Sept. 2011.
$<$ http://www.ams.usda.gov/AMSv1.0/getfile? $\mathrm{dDocName}=$ STELPRDC5050331 $>$.

USDA-ERS. 2010. Vegetables and melons yearbook data. 17 Sept. 2011. <http://usda.mannlib. cornell.edu/usda/ers/89011/89011.pdf $>$.

Waterer, D. and J. Bantle. 2000. High tunnel temperature observations. University of Saskatchewan. 17 Sept. 2011. <http://www.usask.ca/agriculture/ plantsci/vegetable/resources/veg/ht_temp.pdf>.

Watson, C.A., H. Bengtsson, M. Ebbesvik, A.-K. Løes, A. Myrbeck, E. Salomon, J. Schroder, and E.A. Stockdale. 2002. A review of farm-scale nutrient budgets or organic farms as a tool for management of soil fertility. Soil Use Mgt. 18:264-273. 